НУЖОВЙ

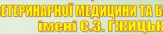

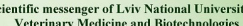
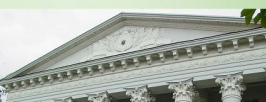

1

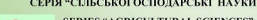

Том 23 № 94 2021
Науковий вісник Дьвівського національного університету ветеринарної медицини та біотехнодогій імені С.3. Гжицького. Серія: Сільськогосподарські науки

\section{Scientific Messenger of Lviv National University} of Veterinary Medicine and Biotechnologies. Series: Agricultural sciences https://nvlvet.com.ua/index.php/agriculture

UDC 712.2(1-751.2)(477.83)

\title{
The use of alternative energy sources in the planning of ecotourism facilities as one of the technological methods of environmental protection
}

\author{
N. Kachmar, T. Datsko, M. Ivankiv, A. Dydiv \\ Lviv National Agrarian University, Dubliany, Ukraine
}

Article info

Received 21.01.2021

Received in revised form 22.02 .2021

Accepted 23.02.2021

Liv National Agrarian University, V. Velykyi, Str., 1, Dubliany, Lviv region, 80381 , Ukraine. Tel: +38-098-096-02-69 E-mail:kachmarnatali@ukr.net
Kachmar, N., Datsko, T., Ivankiv, M., \& Dydiv, A. (2021). The use of alternative energy sources in the planning of ecotourism facilities as one of the technological methods of environmental protection. Scientific Messenger of Lviv National University of Veterinary Medicine and Biotechnologies. Series: Agricultural sciences, 23(94), 16-19. doi: 10.32718/nvlvet-a9403

The article presents the results of research on environmental, energy and economic efficiency of the use of alternative energy sources to provide heat to buildings located on the territory of nature reserves. Spending of time on the territory of the nature reserve fund gives the chance of various kinds of rest: use of bicycle routes, ecological paths, the organized places of recreation, etc. Therefore, in specially designated areas complexes are built for vacationers. They provide them with a comfortable stay and the opportunity to get the most out of the chosen type of recreation. Electricity networks are most often used to provide buildings with electric power on the territory of nature reserve facilities. However, this has a significant negative impact on the environment. Many of these facilities are located at a great distance from the settlements, that increases the cost of electrification and gasification. Such facilities require large investments in hot water and heat. Therefore, alternative energy sources are suitable for such cases. The main advantage of using solar panels and heat pump is their environmental friendliness and long period of operation without major repairs. It is established that for the installation of vertical probes it is enough to use four branches $106 \mathrm{~m}$ long. For this combined system it is necessary to install six solar collectors, which will provide monthly heat production in the amount of $514.03 \mathrm{MJ}$. The use of solar collectors and a heat pump to provide heat to the visitor center will reduce the annual operating costs by 4.63 times compared to the costs required for the operation of a system that would operate on the basis of a gas boiler. The use of a combined heat supply system will make it possible to abandon the use of $7156.3 \mathrm{~kg}$ of conventional fuel and as a result will reduce carbon dioxide emissions in the amount of $7871.9 \mathrm{~kg}$. Our country is interested in the use of renewable energy sources by reducing the cost of traditional energy sources, the overall reduction of greenhouse gas emissions during combustion. The state receives direct income from the sale of quotas for harmful emissions.

Key words: alternative energy sources, solar collectors, heat pump, nature reserve facilities, environmental and economic efficiency.

\section{Використання альтернативних джерел енергії у плануванні екотуристичних об'сктів як один із технологічних методів захисту довкілля}

\author{
Н. В. Качмар, Т. М. Дацко, М. Я. Іванків, А. І. Дидів \\ Львівський національний аграрний університет, м. Дубляни, Украӥна
}

У статті наведені результати досліджень щзодо екологічної, енергетичної та економічної ефективності використання альтернативних джерел енергї для забезпечення теплопостачання будівель, які розташовані на території об'єктів природнозаповідного фонду. Відпочинок на території природно-заповідного фонду дає можливість різноманітного виду відпочинку: використання веломаршрутів, екологічних стежок, організованих місиь рекреачії тошо. Тому у спеціально відведених місиях будуються для відпочиваючих комплекси, які їм забезпечують комфортне перебування і можливість отримати максимум задоволення від обраного виду відпочинку. Для забезпечення будівель електроенергією на території об'єктів природно-заповідного фонду найчас- 
тіше використовують електромережі. Як нам відомо, це справляє значний негативний вплив на навколишнє середовище. Значна кількість цүих об 'єктів - на великій відстані від населених пунктів, щуо підвищує собівартість в процесі електрифікації та газифікачії. Для забезпечення таких об'єктів гарячою водою та теплом потрібні великі капіталовкладення. Тому для таких випадків підходять альтернативні джерела енергї. Головною перевагою застосування сонячних панелей та теплової помпи є їхня екологічна чистота та довгий період експлуатації без капітального ремонту. Встановлено, щзо для влаштування вертикальних зондів достатньо використовувати чотири вітки довжиною по 106 м. Для даної комбінованої системи необхідно встановити шість сонячних колекторів, які забезпечуватимуть місячне виробництво теплоти у кількості 514,03 МДж. Використання сонячних колекторів та теплової помпи з метою забезпечення теплопостачання візит-центру дозволить зменшити річні експлуатаційні витрати у 4,63 раза порівняно з витратами, щчо необхідні для функціонування системи, яка би працювала на базі газового котла. Застосування комбінованої системи теплопостачання дасть можливість відмовитися від застосування 7156,3 кг умовного палива і в результаті дозволить зменшити викиди вуглекислого газу в кількості 7871,9 кг. Держава зацікавлена у використанні відновлюваних джерел енергї через зменшення витрат на традиційні енергоносії, загальне зменшення викидів парникових газів у атмосферу при їх спалюванні. Держава отримує прямий прибуток від продажу квот на шкідливі викиди.

Ключові слова: альтернативні джерела енергіі, сонячні колектори, теплова помпа, об'єкти природно-заповідного фонду, екологічна та економічна ефективність.

\section{Ветуп}

Інтенсивний ритм життя сучасної людини неможливий без відпочинку. Екотуризм на даний час для багатьох жителів урбанізованих територій стає швидкими та помічними “ліками” від повсякденних стресів, задовольняє бажання відпочити безпечно, тихо та пізнавально (Donohoe \& Needham, 2006; Honey, 2008; Boley et al., 2016; Amalu et al., 2018; Kalaitan et al., 2021). Відпочинок на території природно-зоповідного фонду дає можливість різноманітного виду відпочинку: використання веломаршрутів, екологічних стежок, організованих місць рекреації тощо. Проте поряд 3 бажанням опинитися якнайдалі від міського шуму люди не завжди готові відмовитися від повсякденних зручностей. Відпочинок на природі не завжди асоціюється $з$ літнім періодом. Наприклад, Яворівський НПП впродовж двадцяти років проводить такі заходи, як "Бабине літо" наприкінці вересня чи в січні "Йорданське святкування”, які відвідує значна кількість людей, проводяться різноманітні конкурси (Vishnevs'kij, 2015).

Тому у спеціально відведених місцях будуються для відпочиваючих комплекси, які їм забезпечують комфортне перебування і можливість отримати максимум задоволення від обраного виду відпочинку. Певною проблемою $є$ те, що такі комплекси зазвичай розташовані відносно далеко від населених пунктів і тому, щоб забезпечити їх електрикою та газом, необхідні значні затрати коштів. У питаннях використання деревини як палива об'єкти природно-заповідного фонду мають бути прикладом для інших, особливо в час неконтрольованого вирубування лісів. Тому необхідно шукати більш екологічно прийнятні способи забезпечення таких комплексів теплом та електроенергією (Chuchuj, 2015; Slipchenko et al., 2019).

Метою нашого дослідження було продемонструвати можливість та доцільність (розрахувавши економічну та екологічну ефективність) застосування відновлювальних джерел енергії (а саме сонячних колекторів та теплової помпи) для забезпечення теплопостачання просвітницького візит-центру, який розташований на території Яворівського національного природного парку в зоні стаціонарної рекреації “Верещиця".

\section{Матеріал і методи досліджень}

Для висвітлення обраної проблематики проводили аналіз літературних джерел щодо ефективності застосування певних альтернативних джерел енергії; проаналізовано фізико-географічні та кліматичні характеристики району розташування Яворівського національного природного парку; розглянуто технікоекономічні показники проекту: “РовеЛове Розточчя разом, незважаючи на кордони”. Як альтернативне джерело енергії розглядали сонячні колектори та теплову помпу (Erohov, 2015; Slipchenko et al., 2019).

За допомогою online-програми для розрахунку величини теплових втрат будівлі (безкоштовне програмне забезпечення однойменної фірми VALTEC.PRG.3.1.3) було оцінено габаритну потужність теплової помпи.

Розрахунки теплового навантаження об'єкта та параметрів енергетичних засобів комплексної системи енергозабезпечення було проведено, використовуючи методику, яка описана у літературних джерелах (Kudrja \& Golovko, 2009).

Економічну та екологічну ефективність застосування комбінованої системи теплопостачання розраховували, враховуючи ціну на електрику та газ, а також особливості процесу продажу квот на викиди $\mathrm{CO}_{2}$.

\section{Результати та їх обговорення}

Для нормальної життєдіяльності людині потрібне чисте довкілля. Тому актуальним є пошук ефективних способів використання нетрадиційної енергетики. Одним зі шляхів підвищення рівня екологічної та енергетичної безпеки об'єктів зеленого туризму $є$ збільшення рівня енергозабезпеченості за рахунок відновлюваних джерел енергії, оскільки при їхньому правильному і вдалому поєднанні можна досягнути високого рівня коефіцієнта корисної дії функціонування енергетичної системи, а також високого рівня надійності енергозабезпечення в об'єктах зеленого туризму. На початку 2014 року суттєво зросли капіталовкладення у розвиток нетрадиційної енергетики у світі. Цьому сприяло збільшення ціни на нафту (Zakon Ukrainy, 2012; Chuchuj, 2015; Slipchenko et al., 2019). 
На території Яворівського НПП (зона стаціонарної рекреації "Верещиця") - кінцева точка Центрального велосипедного маршруту Розточчя, і саме там будують еколого-просвітницький візит-центр (двоповерхова будівля загальною площею приміщень $294,5 \mathrm{~m}^{2}$ ), призначений для проведення заходів екологічного спрямування та короткострокового відпочинку велотуристів та інших відвідувачів. Згідно з проектом, даний об'єкт газифікувати не планують. Тому для теплопостачання даного об'єкта як альтернативу ми пропонуємо використовувати сонячні панелі та теплову помпу, щоб забезпечити необхідні потужності впродовж цілого року.

Головною перевагою застосування сонячних панелей $є$ їхня екологічна чистота, фотоелементи не $\epsilon$ джерелом утворення небезпечних викидів та не підвищують рівень парникових газів. Тепловий насос $\epsilon$ екологічно чистим, адже не викидає шкідливих речовин у довкілля і має повністю автоматичну систему, яка не потребує постійної присутності людини. Експлуатація складає 20-30 років без капітального ремонту (Kudrja \& Golovko, 2009; DSTU B V.2.544:2010; Erohov, 2015).

У зв'язку з тим, що візит-центр на даний час - на стадії будівництва, неможливо точно розрахувати, які обсяги електроенергії будуть необхідні для нормального функціонування даного об'єкта. Реальні обсяги споживання електроенергії можна буде оцінити лише після першого року експлуатації центру. Тому розпочнемо розрахунки із найбільш енергоємного процесу, а саме із системи теплопостачання.

Основним завданням функціонування системи теплопостачання це $\epsilon$ забезпечити певний об'єкт теплом, яке використовується для опалення і для гарячого водопостачання. 3 метою забезпечення опалення данного об'єкта доцільно використовувати теплову помпу, наприклад типу “грунт-вода", а для гарячого водопостачання - сонячні теплові колектори. У зв'язку з тим, що робота сонячних теплових колекторів $\epsilon$ дещо обмежена i нестабільна у зимовий період, то нестачу теплової енергії пропонуємо компенсувати за рахунок роботи теплової помпи. У цей період року теплову потужність помпи потрібно збільшити. Виходячи з вищевказаного, пропонуємо сформувати комбіновану систему теплопостачання. Відповідно до розрахунку, потужність тепловтрат становить 14912 Вт.

Річне теплове навантаження системи опалення розраховуємо як суму теплових місячних навантажень:

$$
\begin{gathered}
Q_{o n}^{p}=\sum_{i=1}^{12} Q_{o n}^{M} \\
Q_{o n}^{p}=24304+21924+19065+5895+11811+ \\
+17820+22470=123289 \text { МДж. }
\end{gathered}
$$

Помісячну потужність навантаження системи опалення визначаємо за формулою:

$$
\begin{aligned}
P_{m H}^{M} & =\frac{Q_{m u}^{M}}{24 \cdot n \cdot 3600}, \text { КВT } . \quad \text { (2) } \\
P_{m u}^{\mu} & =\frac{24304000}{24 \cdot 31 \cdot 3600}=8,84 \text { кВT. }
\end{aligned}
$$

Помісячні середньодобові навантаження системи гарячого водопостачання 3 використанням середньомісячного значення температури холодної води $t_{x в}$ визначимо як:

$$
Q_{26}^{\partial}=1,2 a c_{p} \rho\left(t_{26}-t_{x b}\right) \cdot N, \text { кДж }
$$

$$
Q_{\imath \varepsilon}^{\partial}=1,2 \cdot 60 \cdot 4,19 \cdot 1 \cdot(45-5,1) \cdot 16 \cdot 10^{-3}=192,59 \text { МДж. }
$$

Розраховуємо середньомісячні значення потужності системи гарячого водопостачання в кіловатах:

$$
\begin{gathered}
P_{2 b}^{M}=1,15 \cdot 10^{-5} \cdot Q_{2 b}^{\partial} \\
P_{2 \varepsilon}^{M}=1,15 \cdot 10^{-5} \cdot 192590=2,21 \mathrm{\kappa BT} .
\end{gathered}
$$

Сумарна потужність теплового навантаження становитиме 11,3 кВт.

Середньоденна тривалість роботи теплової помпи у січні становитиме 10,55 год. Річна витрата електроенергії на потреби теплової помпи буде рівною 6239 кВт.год.

Отже, для візит-центру можна використовувати теплову помпу фірми Viessmann Vitocal 300 типу BW116 (Viessmann. Kniga o solnce, 2010). Встановлено, що для влаштування вертикальних зондів достатньо використовувати чотири вітки довжиною по 106 м. Для даної комбінованої системи необхідно встановити шість сонячних колекторів, які забезпечуватимуть місячне виробництво теплоти у кількості 514,03 МДж.

Отже, застосування комбінованої системи дозволить досягнути високої надійності системи теплопостачання. Також можна досягнути значного підвищення рівня ефективності первинного палива, з якого отримано електроенергію, за рахунок високого коефіцієнта перетворення теплової помпи.

3 метою отримання інформації щодо економічної ефективності використання даної комбінованої системи теплопостачання нами проведено розрахунок, результати якого дають порівняльну характеристику щодо необхідних експлуатаційних затрат впродовж року на функціонування запропонованої системи стосовно затрат, які були би потрібні для роботи газового теплогенератора.

Витрата газу на опалення та гаряче водопостачання газовим котлом

$$
Q p_{\tau \kappa}=\frac{Q_{m n}}{Q_{\kappa}}
$$

де $Q_{\kappa}-$ кількість теплової енергії, яку може виробити газовий котел $31 \mathrm{~m}^{3}$ газу.

$$
Q p_{2 \kappa}=\frac{186678 \cdot 10^{6}}{32,21 \cdot 10^{6}}=5796^{\mathrm{M}^{3}} .
$$

Отже, у разі використання газового котла 3 метою забезпечення даного об'єкта гарячою водою та опалення, витрати газу становили б $5796 \mathrm{~m}^{3}$.

Таким чином, комбінована установка теплоти виробить 186678 МДж теплоти, що потребуватиме електроенергії в розмірі 6504 кВт.год.

Тобто, річні експлуатаційні витрати на теплопостачання з використанням теплової помпи та сонячних колекторів буде у 4,63 раза меншими від системи, яка була би побудована на базі газового котла.

Ефективність системи теплопостачання з використанням відновлюваних джерел енергії оцінюється як 
за економічними, енергетичними, так і за екологічними критеріями. Останній критерій часто подають через узагальнений показник - зменшення викидів вуглекислого газу в атмосферу порівняно 3 попередніми технологіями (Chuchuj, 2015; Slipchenko et al., 2019).

У випадку гібридної системи теплопостачання цей показник розраховується шляхом порівняння їх середньорічної теплової продуктивності $Q_{p}$, вираженої у МДж з кількістю зекономленого палива, вираженого в умовних тоннах або у кг. Маса умовного палива у кг розраховується за його нижчою теплотою згоряння $q_{t}$ з урахуванням к.к.д. відповідного котла.

$$
m=\frac{Q_{p}}{\eta \cdot q_{i}}
$$

Фізичним еквівалентом умовної тони прийнято вважати енергетичне вугілля, основним горючим компонентом якого є вуглець. Для визначення кількості вуглекислого газу запишемо рівняння реакції горіння вуглецю:

$$
\mathrm{C}+\mathrm{O}_{2}=\mathrm{CO}_{2}
$$

За відомими атомними масами елементів - 14, 32 i 44 відповідно визначимо, що при спалюванні 14 кг вугілля утворюється 44 кг вуглекислого газу. Відтак, враховуючи співвідношення (6), використання теплоенергетичної установки запобігає викидам в атмосферу вуглекислого газу, масу $\mathrm{M}$ якого розрахуємо за формулою:

$$
M=\frac{m \cdot 44}{14}=1,1 \cdot m
$$

Провівши розрахунки, встановили, що застосування системи теплопостачання на базі сонячної теплової та теплопомпової установок дозволить уникнути застосування 7156,3 кг умовного палива та зменшити викиди вуглекислого газу в кількості 7871,9 кг. Відповідно можна ще й отримати певний дохід за рахунок продажу квот на викиди $\mathrm{CO}_{2}$.

\section{Висновки}

Серед основних джерел, які визначають стабільність функціонування будь-якого об'єкта, є електрота газопостачання. Екотуристичні будівлі зазвичай розташовані у місцевості, де нема комунікацій, тому для їхньої газифікації та електрифікації необхідні значні капіталовкладення. Тому актуальним є пошук більш екологічно прийнятних способів забезпечення даних об'єктів теплом та електроенергією. Одним зі шляхів підвищення рівня екологічної та енергетичної безпеки об'єктів зеленого туризму є збільшення рівня енергозабезпеченості за рахунок відновлюваних джерел енергії.

Встановлено, що використання сонячних колекторів та теплової помпи з метою забезпечення теплопостачання візит-центру дозволить зменшити річні експлуатаційні витрати у 4,63 раза порівняно 3 витратами, що необхідні для функціонування системи, яка би працювала на базі газового котла.
Розраховано, що застосування комбінованої системи теплопостачання дасть можливість відмовитися від 7156,3 кг умовного палива і в результаті дозволить зменшити викиди вуглекислого газу в кількості 7871,9 кг, а це ще й дає можливість отримати додаткові кошти від продажу квот на викиди $\mathrm{CO}_{2}$.

\section{References}

Amalu, T. E., Otop, O. O., Duluora, E. I., Omeje, V. U., \& Emeana, S. K. (2018). Socio-economic impacts of ecotourism attractions in Enugu state, Nigeria. GeoJournal, 83, 1257-1269. doi: 10.1007/s10708-017-9830-7.

Boley, B. B., \& Green, G. T. (2016). Ecotourism and natural resource conservation: the "potential" for a sustainable symbiotic relationship. Journal of Ecotourism, 15(1), 36-50, doi: 10.1080/14724049.2015.1094080.

Chuchuj, V. P. (2015). Al'ternativni dzherela energii. Odesa: TES (in Ukrainian).

Donohoe, H. M., \& Needham, R. D. (2006). Ecotourism: The Evolving Contemporary. Definition. Journal of Ecotourism, 5(3), 192-210. doi: 10.2167/joe152.0.

DSTU B V.2.5-44:2010. Inzhenerne obladnannja budinkiv i sporud. Proektuvannja sistem opalennja budivel' $\mathrm{z}$ teplovimi nasosami. [Chinnij vid 2010-0901]. Kyiv: Minregionbud Ukraini, IV, 51 (in Ukrainian).

Honey, M. (2008). Ecotourism and Sustainable. — 2nd ed. Washington, USA: Island Press. Retrieved from https:/www.academia.edu/37796180/_Dr_Martha_Ho ney_PhD_Ecotourism_and_Sustainable_b_ok_cc

Kalaitan, T. V., Stybel, V. V., Gutyj, B. V., Hrymak, O. Ya., Kushnir, L. P., Yaroshevych, N. B., Vovk, M. V., \& Kindrat, O. V. (2021). Ecotourism and sustainable development. Prospects for Ukraine. Ukrainian Journal of Ecology, 11(1), 373-383. doi: 10.15421/2021_55.

Kudrja, S. O., \& Golovko, V. M. (2009). Osnovy konstrujuvannja energoustanovok $\mathrm{z}$ vidnovljuvanimi dzherelami energii. Kyiv (in Ukrainian).

Slipchenko, V. G., Koval', O. V., \& Poljagushko, L. G. (2019). Ekologichnij monitoring: al'ternativni dzherela energii: navch. posib. Kyiv: KPI im. I. Sikors'kogo: Politehnika (in Ukrainian).

Viessmann. Kniga o solnce (2010). Rukovodstvo po proektirovaniju sistem solnechnogo teplosnabzhenija. Kyiv: Zlato-Graf (in Russian).

Vishnevs'kij, V. I. (2015). Ekologichnij turizm. Kiiv: Interpres LTD (in Ukrainian).

Zakon Ukrainy (2012). Pro elektroenergetiku shchodo stimuljuvannja virobnictva elektroenergii $\mathrm{z}$ al'ternativnih dzherel energii, vid 20.11.2012 r., № 5485VI (in Ukrainian).

Erohov, V. Ju. (2015). Al'ternativna energetika $\mathrm{Z}$ vikoristannjam sonjachnih elementiv : navch. vid. Nac. un-t "L'viv. Politehnika". L'viv: Spolom (in Ukrainian). 